\title{
Factors Affecting Scholastic Achievement Among School Children in a Slum Area
}

\author{
Amany Sobhy Sorour \\ Community Health Nursing Department, Faculty of Nursing, Zagazig University, Cairo, Egypt
}

\section{Email address:}

dr.amany.sorour@gmail.com

\section{To cite this article:}

Amany Sobhy Sorour. Factors Affecting Scholastic Achievement Among School Children in a Slum Area. American Journal of Nursing Science. Vol. 5, No. 2, 2016, pp. 45-51. doi: 10.11648/j.ajns.20160502.12

Received: February 18, 2016; Accepted: February 29, 2016; Published: March 12, 2016

\begin{abstract}
Slums areas present major social and health disadvantages to children, which may affect their school performance. The aim of this study was to determine the factors affecting scholastic achievement among adolescent children in a slum area. This cross-sectional study was carried out in an urban slum area (Manshiat Naser) in Cairo on a multistage stratified cluster sample of 200 preparatory school children residing in the area technique was used. The data collection tool was an interview questionnaire form covering socio-demographic characteristics, school achievement, and selected domains of the Global Risk Assessment Device (GRAD) scale. The fieldwork was from the beginning of October to the end of December 2015. The results showed that $18 \%$ of children had academic failure. Statistically significant relations were revealed between school achievement and school children's gender $(p=0.001)$, age $(p=0.03)$, grade $(p=0.001)$, father education $(p=0.02)$, mother age $(p=0.19)$, residence $(p=0.01)$, and income $(p<0.001)$. School achievement was also related to the educational $(p<0.001)$, accountability $(\mathrm{p}<0.001)$, and health care $(\mathrm{p}<0.001)$ factors of GRAD. In multivariate analysis, the risk factors predicting academic failure were a higher school grade, and higher scores of educational, accountability, and health care factors. In conclusion, the school performance of school children in slum area is most influenced by accountability, educational and health care factors, and higher school grade. Intervention studies are needed to investigate the effectiveness of school-based programs addressing these identified factors in improving school performance among these adolescents.
\end{abstract}

Keywords: Scholastic Achievement, School Children, Slum, Psychosocial

\section{Introduction}

The challenge of slums is a global concern and a growing one. The rapid urbanization in the last century has been accompanied by tremendous growth of slum areas. Currently, nearly one third of the developing world population and more than $60 \%$ of urban populations in the least developed countries live in slums, including hundreds of millions of children [1]. The world population is expected to increase by 2 billion by 2030 [2]. Approximately half of the population increase is estimated to be in urban slums [3].

The United Nations (UN) operationally defines slums as having at least one of five characteristics: insecure residential status, poor structural quality of housing, overcrowding, inadequate access to safe water, and inadequate access to sanitation and other infrastructure [4]. Slums have also been defined as diverse sets of communities, located centrally and in the periphery of cities, on floodplains and hillsides, poorly constructed and ranging from thousands to millions of residents [5]. In addition to the UN legal and physical definition, the conditions of slum life are characterized by extreme poverty and exceedingly substandard living conditions. They are also areas of broader social disadvantage to children and their families with limited access to basic healthcare, schools and important municipal services. Social problems commonly affect these communities [6].

Slums are areas constitute broad social and health disadvantages to children due to extreme poverty, overcrowding, poor water supply and sanitation, substandard housing, in addition to limited access to basic health and education services, and other hardships [1]. Those children are more likely to not attend school, attend sporadically, or not complete school. They are also vulnerable to being excluded from education for reasons such as low income, 
lack of self-esteem, delayed achievement in education due to non- or sporadic attendance, and lack of literacy and/or education among their parents [7].

Research in recent years has drawn attention to the fact that significant numbers of children and adults are failing to access educational opportunities. Internationally, 61 million children and 74 million adolescents are out of school, most of them in Sub-Saharan Africa and South Asia [8]. Moreover, 793 million people do not have basic literacy skills and current trends indicate that the number of children not in school in 2015 may be higher than it was in 2012 [7]. Of additional concern is the fact that those who are accessing education are often either not learning effectively or dropping out before completing primary education. Thus, in many countries, few children progress from primary to secondary schools. Most data indicates that children from economically poorer families are significantly more likely to drop out of secondary school even if they do enroll, reinforcing the link between poverty and lack of access to education [9].

Aim of the study: The aim of this study was to determine the factors affecting scholastic achievement among school children in a slum area.

\section{Subjects and Methods}

\subsection{Research Setting and Design}

The study was carried out in an urban slum area (Manshiat Naser) in Cairo. A cross-sectional design was used to achieve the aim of the study.

\subsection{Subjects}

The study population consisted of preparatory school children residing in the study setting during the time of data collection. Any school child permanently residing in this area and attending one of its schools was eligible for inclusion in the study. The sample size was calculated to detect a medium effect size of the mean differences in the scores of the factors probably affecting scholastic achievement related to substance abuse, health services, accountability, sociability, and education between success and failure students. A total sample of 200 school children was required to identify this difference at $95 \%$ level of confidence and $80 \%$ power for unequal groups [10].

In order to achieve the required sample size, a multistage stratified cluster sampling technique was used. Thus, schools were stratified into schools for boys and schools for girls, and the classes were stratified into three according to grade levels. Two schools were randomly selected, one for boys and one for girls. Then, three classes were randomly selected from each school, one from each of the three grades. One class was randomly selected from each of the three grades for boys and girls. All available school children in the selected classes were recruited in the study sample.

\subsection{Data Collection Tool}

The researcher prepared an interview questionnaire form for data collection. Its first part covered respondent's sociodemographic characteristics as age, gender, school grade, school achievement, residence, parents' education, job, and income. The second part consisted selected domains of the Global Risk Assessment Device (GRAD) scale, version 1.0 developed by Gavazzi et al. [11]. The domains of risks selected to determine the factors possibly affecting scholastic achievement were substance abuse (13 items such as does the youth use marijuana?, does the youth smokes or chews tobacco regularly?, does the youth sniff glue, aerosol sprays, or other inhalants?), health services (5 items such as does the youth have poor nutrition or hunger-related problems?, does the youth have problems with their weight (either over or under?), accountability ( 7 items such as does the youth fail to take responsibility for their actions?, does the youth seem to not feel guilty when caught doing something wrong?, does the youth blame others for their own mistakes?), sociability (7 items such as does the youth seem to have an excessive sense of self-worth?, does the youth seem to think they are better or more deserving than others?, and education (13 items such as does the youth have difficulty getting to school/or staying in school for the entire day? does the youth miss school frequently due to family responsibilities?).

The response to each item is on a 3-point Likert scale "No/Never," "Yes/a couple of times," and "Yes/a lot" depending on how much each item applies to respondent's life. These are scored "0" to "2" respectively, so that a higher score reflects a greater risk in each domain. The item scores of each domain are totaled by simple summation and divided by the number of its items to compute a risk score for each domain ranging between 0 and 2. Evidence of the psychometric properties of the GRAD has been demonstrated in studies that demonstrated high internal reliability, predictive validity [11], and gender and race/ethnicity differences [12].

\subsection{Pilot Study}

This was carried out on 20 children from different classes to test the feasibility of the study and the clarity of the questionnaire, and to estimate the time needed for data collection. Since some modifications were done in the tool in the form of re-wording and re-phrasing, those 20 children who participated in the pilot study were not included in the main study sample.

The pilot study also served to assess the reliability of the scales used through assessing their internal consistency. The scales showed good reliability with Cronbach alpha coefficients 0.83 for educational factors, 0.78 for substance abuse, 0.54 for sociability, 0.69 for accountability, and 0.60 for health care.

\subsection{Fieldwork}

The researcher obtained an official permission letter for data collection from the CAPMAS security department directed to the Department of Education at Manshiat Naser Zone. Two schools were selected randomly one for girls and 
one for boys. The researcher met with the headmaster of each school to explain the aim and procedures, to set the time schedule for data collection, and to arrange for obtaining parents' consents and students' assents. Eligible students were met in the presence of a social worker after explaining to them the aim of the study. The researcher then started to interview them in small groups of 3 to 5 using the questionnaire form. The interview was started by providing instructions to the students on filling the form; then the researcher read each statement and gave the students the chance to respond to each one. The process took approximately 40-50 minutes. Two days were scheduled each week for data collection from schools. The duration of data collection took about three months from the beginning of October to the end of December 2015.

\subsection{Ethical Considerations}

Informed consents were obtained from the parents of children through their schools or literacy classes and assents from the children themselves. The form explained the study aim in a simple and clear manner to be understood by common people. No harmful maneuvers were performed or used, and no foreseen hazards were anticipated from conducting the study on participants. They were informed about their right to withdraw from the study at any time without giving any reason. Data were considered confidential and not to be used outside this study without their approval.

\subsection{Statistical Analysis}

Data entry and statistical analysis were done using SPSS 20.0 statistical software package. Data were presented using descriptive statistics in the form of frequencies and percentages for qualitative variables, and means and standard deviations and medians for quantitative variables. Cronbach alpha coefficient was calculated to assess the reliability of the scales through internal consistency. Qualitative categorical variables were compared using chi-square test. Whenever the expected values in one or more of the cells in a $2 \times 2$ tables was less than 5, Fisher exact test was used instead. In larger than $2 \times 2$ cross-tables, no test could be applied whenever the expected value in $10 \%$ or more of the cells was less than 5 . pearman rank correlation was used for assessment of the interrelationships among quantitative variables and ranked ones. In order to identify the independent predictors of academic failure, multiple logistic regression analysis was used. Statistical significance was considered at $\mathrm{p}$-value $<0.05$.

\section{Results}

Table 1 shows that the age of school children ranged between 13 and 15 years, with more males (56\%), and 44\% from the second preparatory grade. Slightly less than onefifth of them (18\%) experienced academic failure. As regards their parents, the mean ages of the fathers and mothers were 42.9 and 36.9 years, with a majority having no formal education, $84.8 \%$ and $93 \%$ respectively. Approximately three-fourth of the fathers were manual workers $(73.1 \%)$. The majority of the families were from rural areas $(70.5 \%)$, and $52.5 \%$ had insufficient income.

Table 1. Socio-demographic and educational characteristics of school children in the study sample $(n=200)$.

\begin{tabular}{|c|c|c|}
\hline Characteristics & Frequency & Percent \\
\hline \multicolumn{3}{|l|}{ Gender: } \\
\hline Male & 112 & 56.0 \\
\hline Female & 88 & 44.0 \\
\hline \multicolumn{3}{|l|}{ Age: } \\
\hline 13 & 56 & 28.0 \\
\hline 14 & 83 & 41.5 \\
\hline 15 & 61 & 30.5 \\
\hline Range & $13.0-15.0$ & \\
\hline Mean \pm SD & $14.0 \pm 0.8$ & \\
\hline Median & 14.0 & \\
\hline \multicolumn{3}{|l|}{ School grade: } \\
\hline 1 & 63 & 31.5 \\
\hline 2 & 88 & 44.0 \\
\hline 3 & 49 & 24.5 \\
\hline \multicolumn{3}{|c|}{ School achievement: } \\
\hline Success & 164 & 82.0 \\
\hline Failure & 36 & 18.0 \\
\hline \multicolumn{3}{|l|}{ Father age: } \\
\hline$<40$ & 39 & 19.5 \\
\hline $40+$ & 161 & 80.5 \\
\hline Range & $30.0-65.0$ & \\
\hline Mean \pm SD & $42.9 \pm 6.2$ & \\
\hline Median & 41.00 & \\
\hline \multicolumn{3}{|l|}{ Father education: } \\
\hline None & 167 & 84.8 \\
\hline Educated & 30 & 15.2 \\
\hline \multicolumn{3}{|l|}{ Father job: } \\
\hline Employee & 38 & 19.3 \\
\hline Manual worker & 144 & 73.1 \\
\hline Retired/non & 15 & 7.6 \\
\hline \multicolumn{3}{|l|}{ Mother age: } \\
\hline$<35$ & 67 & 33.5 \\
\hline $35+$ & 133 & 66.5 \\
\hline Range & $22.0-60.0$ & \\
\hline Mean \pm SD & $36.9 \pm 5.9$ & \\
\hline Median & 37.00 & \\
\hline \multicolumn{3}{|c|}{ Mother education: } \\
\hline None & 185 & 93.0 \\
\hline Educated & 14 & 7.0 \\
\hline \multicolumn{3}{|l|}{ Residence: } \\
\hline Rural & 159 & 79.5 \\
\hline Urban & 41 & 20.5 \\
\hline \multicolumn{3}{|l|}{ Income: } \\
\hline Insufficient & 105 & 52.5 \\
\hline Sufficient & 95 & 47.5 \\
\hline
\end{tabular}

Table 2 demonstrates statistically significant relations between school achievement and school children's gender $(p=0.001)$, age $(p=0.03)$, grade $(p=0.001)$, father education $(\mathrm{p}=0.02)$, mother age $(\mathrm{p}=0.19)$, residence $(\mathrm{p}=0.01)$, and income $(\mathrm{p}<0.001)$. As evident from the table, the failed school children had higher percentages of males, older age, higher school grade, non-educated fathers, older age mothers, 
with rural residence, and insufficient income.

Concerning the psychosocial factors and their relation to school achievement, Table 3 demonstrates statistically significant associations with the educational $(\mathrm{p}<0.001)$, accountability $(\mathrm{p}<0.001)$, and health care $(\mathrm{p}<0.001)$ factors. It can be noticed that these three factors were higher among failed school children. Meanwhile, the substance abuse and sociability factors were not significantly different in success and failure school children.

Table 2. Relation between school achievement and school children characteristics.

\begin{tabular}{|c|c|c|c|c|c|c|}
\hline \multirow{3}{*}{ characteristics } & \multicolumn{4}{|c|}{ School achievement } & \multirow{3}{*}{$\begin{array}{l}X^{2} \\
\text { test }\end{array}$} & \multirow{3}{*}{ p-value } \\
\hline & \multicolumn{2}{|c|}{ Success } & \multicolumn{2}{|c|}{ Failure } & & \\
\hline & No. & $\%$ & No. & $\%$ & & \\
\hline \multicolumn{7}{|l|}{ Gender: } \\
\hline Male & 83 & 50.6 & 29 & 80.6 & & \\
\hline Female & 81 & 49.4 & 7 & 19.4 & 10.74 & $0.001 *$ \\
\hline \multicolumn{7}{|l|}{ Age: } \\
\hline 13 & 51 & 31.1 & 5 & 13.9 & & \\
\hline 14 & 69 & 42.1 & 14 & 38.9 & & \\
\hline 15 & 44 & 26.8 & 17 & 47.2 & 7.22 & $0.03 *$ \\
\hline \multicolumn{7}{|l|}{ School grade: } \\
\hline 1 & 58 & 35.4 & 5 & 13.9 & & \\
\hline 2 & 74 & 45.1 & 14 & 38.9 & 13.84 & $0.001 *$ \\
\hline 3 & 32 & 19.5 & 17 & 47.2 & & \\
\hline \multicolumn{7}{|l|}{ Father age: } \\
\hline$<40$ & 34 & 20.7 & 5 & 13.9 & & \\
\hline $40+$ & 130 & 79.3 & 31 & 86.1 & 0.88 & 0.35 \\
\hline \multicolumn{7}{|l|}{ Father education: } \\
\hline None & 132 & 82.0 & 35 & 97.2 & & \\
\hline Educated & 29 & 18.0 & 1 & 2.8 & 5.29 & $0.02 *$ \\
\hline \multicolumn{7}{|l|}{ Father job: } \\
\hline Employee & 34 & 21.1 & 4 & 11.1 & & \\
\hline Manual worker & 120 & 74.5 & 24 & 66.7 & -- & -- \\
\hline Retired/non & 7 & 4.3 & 8 & 22.2 & & \\
\hline \multicolumn{7}{|l|}{ Mother age: } \\
\hline$<35$ & 61 & 37.2 & 6 & 16.7 & & \\
\hline $35+$ & 103 & 62.8 & 39 & 83.3 & 5.584 & $0.019 *$ \\
\hline
\end{tabular}

\begin{tabular}{|c|c|c|c|c|c|c|}
\hline \multirow{3}{*}{ characteristics } & \multicolumn{4}{|c|}{ School achievement } & \multirow{3}{*}{$\begin{array}{l}X^{2} \\
\text { test }\end{array}$} & \multirow{3}{*}{ p-value } \\
\hline & \multicolumn{2}{|c|}{ Success } & \multicolumn{2}{|c|}{ Failure } & & \\
\hline & No. & $\%$ & No. & $\%$ & & \\
\hline \multicolumn{7}{|c|}{ Mother education: } \\
\hline None & 149 & 91.4 & 36 & 100.0 & & \\
\hline Educated & 14 & 8.6 & 0 & 0.0 & Fisher & 0.08 \\
\hline \multicolumn{7}{|l|}{ Residence: } \\
\hline Rural & 125 & 76.2 & 34 & 94.4 & & \\
\hline Urban & 39 & 23.8 & 2 & 5.6 & 6.02 & $0.01 *$ \\
\hline \multicolumn{7}{|l|}{ Income: } \\
\hline Insufficient & 74 & 45.1 & 31 & 86.1 & & \\
\hline Sufficient & 90 & 54.9 & 5 & 13.9 & 19.89 & $<0.001 *$ \\
\hline
\end{tabular}

(*) Statistically significant at $\mathrm{p}<0.05$ (--) Test result not valid

Table 4 illustrates statistically significant weak moderate positive correlations among the scores of the various groups of psychosocial factors influencing school achievement. The only exception was the sociability factor, which was not correlated to any of the other factors. It is noticed that the strongest correlation was between educational and health care factors $(\mathrm{r}=0.552)$, while the weakest was between accountability and substance abuse $(\mathrm{r}=0.211)$.

As regards the correlations between the various psychosocial factors and schoolchildren's characteristics, Table 5 indicates that the educational, substance abuse, and health care factors had negative correlations with the level of father and mother education. Meanwhile, substance abuse had positive correlations with school child's age, school grade, and mother age. The sociability and accountability factors had no significant correlations with any of the characteristics of school children.

In multivariate analysis (Table 6), the risk factors predicting academic failure were a higher school grade, and higher scores of educational, accountability, and health care factors. It is evident that the educational factors are the most influential (Odds Ratio [OR] 186.52), followed by the accountability factors (OR 37.34).

Table 3. Relation between total factors and school achievement among school children in the study sample.

\begin{tabular}{|c|c|c|c|c|c|c|}
\hline \multirow{3}{*}{ Factors } & \multicolumn{4}{|c|}{ School achievement } & \multirow{3}{*}{$\mathrm{X}^{2}$ test } & \multirow{3}{*}{ p-value } \\
\hline & \multicolumn{2}{|c|}{ Success } & \multicolumn{2}{|c|}{ Failure } & & \\
\hline & No. & $\%$ & No. & $\%$ & & \\
\hline \multicolumn{7}{|c|}{ Educational factors: } \\
\hline High & 28 & 17.1 & 34 & 94.4 & & \\
\hline Low & 136 & 82.9 & 2 & 5.6 & 82.62 & $<0.001 *$ \\
\hline \multicolumn{7}{|c|}{ Substance abuse: } \\
\hline High & 5 & 3.0 & 0 & 0.0 & & \\
\hline Low & 159 & 97.0 & 36 & 100.0 & Fisher & 0.59 \\
\hline \multicolumn{7}{|c|}{ Sociability: } \\
\hline High & 18 & 11.0 & 1 & 2.8 & & \\
\hline Low & 146 & 89.0 & 35 & 97.2 & Fisher & 0.21 \\
\hline \multicolumn{7}{|c|}{ Accountability: } \\
\hline High & 32 & 19.5 & 30 & 83.3 & & \\
\hline Low & 132 & 80.5 & 6 & 16.7 & 56.21 & $<0.001 *$ \\
\hline \multicolumn{7}{|c|}{ Health care: } \\
\hline High & 59 & 36.0 & 33 & 91.7 & & \\
\hline Low & 105 & 64.0 & 3 & 8.3 & 36.86 & $<0.001 *$ \\
\hline
\end{tabular}

(*) Statistically significant at $\mathrm{p}<0.05$ 
Table 4. Correlation matrix of various domains scores.

\begin{tabular}{lllll}
\hline \multirow{2}{*}{ Factors } & \multicolumn{2}{l}{ Spearman's rank correlation coefficient } & & Accountability \\
\cline { 2 - 5 } & Educational & Substance Abuse & Sociability & \\
\hline Educational & & & & \\
Substance abuse & $.418^{* *}$ & -0.04 & & \\
Sociability & 0.00 & $.211^{* *}$ & 0.12 & $.529^{* *}$ \\
Accountability & $.471^{* *}$ & $.235^{* *}$ & 0.06 & \\
Health care & $.552^{* *}$ & & \\
\hline
\end{tabular}

(**) Statistically significant at $\mathrm{p}<0.01$

Table 5. Correlation matrix of various domains scores with students' characteristics.

\begin{tabular}{|c|c|c|c|c|c|}
\hline \multirow{2}{*}{ Characteristics } & \multicolumn{5}{|c|}{ Spearman's rank correlation coefficient } \\
\hline & Educational & Substance Abuse & Sociability & Accountability & Health care \\
\hline Age & 0.08 & $.286^{* *}$ & 0.02 & 0.10 & 0.03 \\
\hline Grade & 0.01 & $.250 * *$ & 0.05 & 0.11 & 0.04 \\
\hline Father age & -0.01 & 0.10 & -0.03 & -0.02 & 0.00 \\
\hline Father education & $-.203 * *$ & $-.192 * *$ & -0.02 & -0.08 & $-.143 *$ \\
\hline Mother age & 0.05 & $.183 * *$ & -0.02 & 0.06 & 0.02 \\
\hline Mother education & $-.274 * *$ & $-.173 *$ & -0.10 & -0.11 & $-.201 * *$ \\
\hline
\end{tabular}

(*) Statistically significant at $\mathrm{p}<0.05(* *)$ Statistically significant at $\mathrm{p}<0.01$

Table 6. Best fitting multiple logistic regression model for school failure.

\begin{tabular}{|c|c|c|c|c|c|c|}
\hline \multirow{2}{*}{ Factors } & \multirow{2}{*}{ Wald } & \multirow{2}{*}{ Df } & \multirow{2}{*}{$\mathbf{P}$} & \multirow{2}{*}{ OR } & \multicolumn{2}{|c|}{$95.0 \%$ CI for OR } \\
\hline & & & & & Upper & Lower \\
\hline Constant & 23.308 & 1 & $<0.001$ & 0.00 & & \\
\hline Grade & 10.900 & 1 & 0.001 & 7.59 & 2.28 & 25.27 \\
\hline Educational factors score & 18.582 & 1 & $<0.001$ & 186.52 & 17.31 & 2009.83 \\
\hline Accountability factors score & 16.700 & 1 & $<0.001$ & 37.34 & 6.58 & 211.97 \\
\hline Health care factors score & 4.134 & 1 & .042 & 6.23 & 1.07 & 36.33 \\
\hline \multicolumn{7}{|l|}{ Nagelkerke R Square: 0.82} \\
\hline \multicolumn{7}{|c|}{ Omnibus Tests of Model Coefficients: $\mathrm{p}<0.001$} \\
\hline Variables entered and exclud & rentc', & & & & & \\
\hline
\end{tabular}

\section{Discussion}

The examination of factors associated with educational achievements is a high interesting area of research in educational systems. The present study attempted to identify these factors in a specific population of school children, those residing in a slum area. The results identified important personal as well as family, psychological and environmental factors that had significant associations with their scholastic achievement.

The present study results revealed that the educational, accountability, and health care risk factors had a significant association with academic failure. The multivariate analysis confirmed that these three factors were the psychosocial predictors of academic failure; the educational risk factors being the most influential. This is plausible since factors such as the educational system and student's compliance with rules and with regular attendance are expected to be of prime importance in achieving academic success. In congruence with this, Reimer and Smink [13] found that the students with high absenteeism are significantly more involved with disruptive classroom behaviors such as bullies/bullied, disrespect for teacher, and affiliation with gangs. Such behaviors would certainly have a negative impact on their academic achievement. Moreover, a harsh school discipline was reported to be associated with poor academic performance among school children in South Africa and Malawi [14].

In the present study, the accountability risk factors came second as predictor of school failure following the educational risk factors. The findings reflect the importance of feeling responsible and committed in improving school performance, especially in the poor school environment such as in slums. In line with this, Özenl [15] demonstrated that a positive school climate improves student achievement with a more sense of belonging. Additionally learning and behaving responsibly in the classroom are causally related. Thus, irresponsible behavior can result in classroom disorder or poor interpersonal relationships and tends to place children at risk for academic failure. Thus, student's accountability can be instrumental in the acquisition of knowledge and the development of cognitive abilities. On the same line, a recent study in Spain identified a significant association between students' feeling of lack of autonomy and poor school performance [16].

The effect of health care risk factors are quite expected given the close relationship between good nutrition and school performance. Thus, a deficient health care system, such as it is the case in slum areas, is would certainly have a negative impact of scholastic achievement. In agreement with this, Lowry [17] mentioned that healthy students are better on all levels of academic achievement. A student who is 
malnourished, unable to hear and see adequately, or living with an unmanaged health condition may have more problems concentrating in class and miss more school days than a healthy one. Health issues may thus impair students' ability to fully participate in school. This is also more aggravated by unhealthy school settings that do not allow adequate access to basics like physical activity, health services, quality indoor air conditions, healthy food and drinkable water. In this respect studies have demonstrated significant associations between poor health [18], as well as exposure to environmental pollutants such as lead in studies in the United States (Evens et al. [19] and in Sweden (Skerfving et al. [20], which may be more likely in slum areas, and poor school performance among adolescent students. Hence, García-Vázquez [21] in a study in Spain showed the positive impact of a good school health program on students' academic achievement.

Unexpectedly, the substance abuse risk factors showed no significant difference between successful and failed school children. This might have more than one explanation. The first is the denial and under-reporting of substance abuse for fear or shame. The second is the high prevalence of this problem in slum areas. These two reasons may mask any significant association between substance abuse risk factors and scholastic achievement. In congruence with this, Hollar and Moore clarified [22] that although substance abuse is a major problem among adolescents, studies rarely investigate the relationships between substance abuse educational achievement because of denial reasons. Hence, attempts were done to develop valid tools to diagnose substance abuse among adolescents Couwenbergh et al. [23]. Meanwhile, some researchers suggested that substance abuse is an outcome rather than a cause of poor school performance [24; 25].

According to the present study results, the sociability risk factors were not significantly different in success and failure school children. This might be attributed to the fact that such risk factors related to low self-esteem, easily irritability, and feeling of inferiority are highly prevalent in slum areas. Since the majority of children suffer these negative feelings, they could not differentiate success from failure students. Hence, our results are incongruent with previous studies, which demonstrated that high self-esteem and good academic achievement and personal development are closely related [26; 27]. Moreover, Maruyama et al. [28] found that students who generally feel confident show better performance in all areas of their studies whereas those who demonstrate less confidence show low performance. The discrepancy with our results could be related to the different settings since the present study was carried out in a slum area where the sociability risk factors are highly prevalent.

Concerning the personal and family characteristics as factors possibly affecting school achievement in a slum area, the present study revealed that male gender, older age, and higher-grade students experienced significantly more academic failures. However, in multivariate analysis the only personal risk factor predicting academic failure was a higher school grade, This might be explained by the fact that as students progress to higher school grades, especially male ones, they tend to gradually withdraw from education. This is associated with decrease in their school performance, ending up with academic failure. The findings are similar to those reported by Bunketorp et al. [29] in a study in Sweden, where girls had better academic achievements.

The family characteristics associated with a higher likelihood of academic failure in the current study were the fathers having no formal education, older age mothers, rural residence, and insufficient income. These factors indicating low socio-economic level often lead families to force their children to quit the school to work in order to help in family financial support. In agreement with this, Ruijsbroek et al. [30] in a study in the Netherlands demonstrated that parents' education and children's academic achievement are strongly positively related. Furthermore, a recent study in Brazil showed that low home environment resources is significantly associated with low academic success in primary school children [31]. Moreover, the school performance of children of affluent families was found significantly better compared with those of poor families in a study in Russia [32].

\section{Conclusion and Recommendations}

In conclusion, the school performance of school children in slum area is most influenced by accountability, educational and health care factors, in addition to higher school grade. The strong inter-relations among these domains should be taken into account in any trial to improve the educational system in schools. The substance abuse-related factors need to be revisited given the possibility of under-reporting. Intervention studies are needed to investigate the effectiveness of school-based programs addressing these identified factors in improving school performance among these adolescents.

\section{References}

[1] Unger A. (2013): Children's health in slum settings Arch Dis Child; 0: 1-7. doi: 10.1136/archdischild-2011-301621.

[2] Pitcher H. M. (2009): The future of scenarios: issues in developing new climate change scenarios. Environmental Research Letters; 2(025002).

[3] UN-Habitat (2008): State of the world's cities 2008/2009 harmonious cities. London e Sterling, VA: United Nations Human Settlements Programme.

[4] UN-HABITATT (2015): Housing and Slum Upgrading. Retrieved on January 10, 2016 at: http://unhabitat.org/urbanthemes/housing-slum-upgrading/

[5] Davis M. (2006): Planet of slums. London, New York: Verso, p.228.

[6] UN- HABITAT (2003): UNHSP The challenge of the slums: global report on human settlements. Nairobi: United Nations, 2003.

http://www.unhabitat.org/downloads/docs/GRHS.2003.0. pdf (accessed 12 Oct 2012). 
[7] UNESCO (2011): The hidden crisis: Armed conflict and education EFA Global Monitoring Report, Oxford/ Paris: UNESCO.

[8] CREATE (2011): Making Rights Realities: Researching Educational Access, Transitions and Equity, Consortium for Research on Educational Access, Transitions \& Equity, University of Sussex/DFID.

[9] UIS (2012): Reaching Out-of-School Children Is Crucial for Development, UIS Fact Sheet No. 18, http:// www.uis.unesco.org/Education/Documents/fs-18-OOSC2.pdf.

[10] Schlesselman J. (1982): Case control studies: design, conduct, analysis. Oxford Uni. Press, New York, pp 145-146.

[11] Gavazzi S. M., Lim J. Y., Yarcheck C. M., and Eyre E. L. (2003): A brief report regarding predictive validity evidence of global risk indicators in the lives of court-involved youth. Psychological Reports; 93: 1239-1242.

[12] Gavazzi S. M. (2006): Gender, ethnicity, and the family environment: Contributions to assessment efforts within the realm of juvenile justice. Family Relations; 55 (2): 190-199.

[13] Reimer M., and Smink J. (2005): Information About the School Dropout Issue Selected Facts \& Statistics. A Publication of the National Dropout Prevention Center/Network.

[14] Sherr L., Hensels I. S., Skeen S., Tomlinson M., Roberts K. J., and Macedo A. (2007): Exposure to violence predicts poor educational outcomes in young children in South Africa and Malawi. Int Health. 2015 Dec 17. pii: ihv070. [Epub ahead of print].

[15] Özenl Y. (2012): A social psychological approach: relationship between social responsibility and student achievement. http://www.akademikbakis.org

[16] Vitale R., Degoy E., and Berra S. (2015): [Perceived health and academic performance among adolescents from public schools in the city of Córdoba]. [Article in Spanish] Arch Argent Pediatr.; 113(6): 526-33.

[17] Lowry F. (2010): Prevalence of chronic illness in US kids has increased. Medscape Medical News. Retrieved from http://www.medscape.com

[18] Crump C., Rivera D., London R., Landau M., Erlendson B. and Rodriguez E. (2013): Chronic health conditions and school performance among children and youth. Ann $\begin{array}{llll}\text { Epidemiol.; } & \text { 23(4): } & \text { 179-84. }\end{array}$ 10.1016/j.annepidem.2013.01.001. Epub 2013 Feb 12.

[19] Evens A., Hryhorczuk D., Lanphear B. P., Rankin K. M., Lewis D. A., Forst L., and Rosenberg D. (2015): The impact of lowlevel lead toxicity on school performance among children in the Chicago Public Schools: a population-based retrospective cohort study. Environ Health.; 14: 21. doi: 10.1186/s12940015-0008-9.

[20] Skerfving S., Löfmark L., Lundh T., Mikoczy Z., and Strömberg $U$. (2015): Late effects of low blood lead concentrations in children on school performance and cognitive functions. Neurotoxicology.; 49: 114-20. doi: 10.1016/j.neuro. 2015.05.009. Epub 2015 May 27.

[21] Garcia-Vázquez J. (2014): Effects of the School for Health network on students' behaviour in Asturias (Spain). Health Promot Int. 2014 Sep 10. pii: dau076. [Epub ahead of print]

[22] Hollar D., and Moore D. (2004): Relationship of substance use by students with disabilities to long-term educational, employment, and social outcomes. Subst Use Misuse; 39: 931-962.

[23] Couwenbergh C., Van Der Gaag R. J., Koeter M., De Ruiter $C$., and Van den Brink W. (2009): Screening for substance abuse among adolescents validity of the CAGE-AID in youth mental health care. Subst Use Misuse.; 44(6): 823-34. doi: $10.1080 / 10826080802484264$.

[24] Singleton R. A. (2007): Collegiate alcohol consumption and academic performance. J. Stud. Alcohol Drugs; 68: 548-555.

[25] Bachman J. G., O'Malley P. M., Schulenberg J. E., Johnston L. D., Freedman-Doan P., and Messersmith E. E. (2008): The Education-drug Use Connection: How Successes and Failures in School Relate to Adolescent Smoking, Drinking, Drug Use, and Delinquency; New York, NY, USA: Lawrence Erlbaum Associates/Taylor \& Francis.

[26] Valtolina G. G., and Colombo C. (2012): Psychological wellbeing, family relations, and developmental issues of children left behind. Psychol Rep.; 111(3): 905-28.

[27] Kiviruusu O., Huurre T., Aro H., Marttunen M., and Haukkala $A$. (2015): Self-esteem growth trajectory from adolescence to mid-adulthood and its predictors in adolescence. Adv Life Course Res.; 23: 29-43. doi: 10.1016/j.alcr.2014.12.003. Epub 2014 Dec 24.

[28] Maruyama G. M., Rubin R. A., and Kingsbury G. G. (1981): Self-esteem and educational achievement: Independent constructs with a common cause? Journal of Personality and Social Psychology; 40(5): 623-655.

[29] Bunketorp Käll L., Malmgren H., Olsson E., Lindén T., and Nilsson M. (2015): Effects of a Curricular Physical Activity Intervention on Children's School Performance, Wellness, and Brain Development. J Sch Health.; 85(10): 704-13. doi: 10.1111/josh.12303.

[30] Ruijsbroek A., Wijga A. H., Gehring U., Kerkhof M., and Droomers M. (2015): School Performance: A Matter of Health or Socio-Economic Background? Findings from the PIAMA Birth Cohort Study. PLoS One.; 10(8): e0134780. doi: 10.1371/journal.pone.0134780. eCollection 2015.

[31] Pereira S., Santos J. N., Nunes M. A., Oliveira M. G., Santos T. S., and Martins-Reis Vde O. (2015): Health and education: a partnership required for school success. Codas.; 27(1): 5864. doi: 10.1590/2317-1782/20152014053.

[32] Iovleva N. N., and Soroko S. I. (2015): [Influence of social factors on personal social and psychological adaptation and functional state of the cns in northern children]. [Article in Russian] Ross Fiziol Zh Im I M Sechenova.; 101(6): 731-44. 